\title{
Difference in Academic Performance of Students from Dual and Single Parenthoods in Public Day Secondary Schools in Nakuru Municipality.
}

\author{
Betty C. W. Murage -Kisoi \\ Kabarak University P.o. Box 3270 Nakuru. Kenya
}

\begin{abstract}
The effects parents have on growing children cut across all the areas of their lives, academics and career included. The academic performance of most public day secondary school students in Nakuru Municipality is below average. This study sought to determine the influence of types of parenthoods on academic performance of public day secondary school students in Nakuru Municipality, Kenya. This study adopted cross-sectional survey design. The target population comprised of form 3 students, both boys and girls in the public day secondary schools in Nakuru Municipality. The study used a sample size of 5 schools of the population of public day secondary schools. The 5 schools were sampled randomly. Students' sample size was 145. Out of the 145 students, 78 students came from dual parent families, 39 boys and 39 girls. Sixty seven students hailed from single parent families, 37 boys and 30 girls. Stratified Random sampling was employed to sample students from dual parenthood type. Purposive sampling was employed to sample students from single parenthoods. Two sets of questionnaires were used to collect data. Data was analyzed using Statistical Package for Social Sciences for Windows. The findings of this study indicated that type of parenthood does influence students' academic performance.
\end{abstract}

Keywords: - Academic Performance, Dual \& Single Parenthoods, Secondary Schools, Nakuru Municipality.

\section{INTRODUCTION}

Parenthood is the process of raising children from infants to adults who will provide continuity within the family for years to come (Oslon \&Defrain, 2000). Many factors influence development of children but parenthood is the "final common pathway" to childhood care giving, development and stature, adjustment and success (Henslin, 2006). Parenting today however is faced by many challenges on account of strong secular and historical trends operating in modern society. Industrialization, urbanization, globalization, poverty and widespread dual parent employment, rise of single-parent headed families are some of these challenges (Rice, 1990). These society - wide changes exert many influences on parenthood, on interactions between parents and children and consequently on children and their overall development (Oslon \& Defrain, 2000). Overall, the quality of parenting and family relations strongly affect children's social, psychological and academic adjustments in both two-parent and single-parent families.

The government of Kenya in conjunction with UNICEF and the Family Support Institute carried out a study in 13 districts in Kenya to establish types of parenthood. The findings of the study were that two -parent families constituted $45 \%$ of the total sample, single -parent families constituted 39\%, (30\% were female-headed and $9 \%$ were male-headed), extended families constituted $8.7 \%$, grand-parent families constituted $2.3 \%$ whereas child-headed families were $5 \%$ of the total families sampled. Most of the single-parent families headed by mothers lived below the poverty line in Kenya (Family Support Institute 1995 as cited in Kimani, 2006). Seventy percent of the female-headed single parents were unmarried teenage mothers. In the year 2008, 53\% of all those parents who applied for bursary funds allocation for school fees in Nakuru Municipality were singleparents. The other $47 \%$ of the Bursary fund applications were from orphaned students, students from dual parent families and from other family configurations (Nakuru Bursary Fund committee, 2009)

\section{LITERATURE REVIEW}

\section{PARENTHOOD}

Parenthood is a process where a person has children either naturally or through adoption .The person takes up the responsibility to bring up the child. The family remains one of the most significant contributors to individuals' feelings about the quality of their lives (Lauer \&Lauer, 2002). For the first several years of life, at least, families provide the main settings in which children's fundamental needs are met. The parents supply most of the love, nurturing and care that children need in order to develop basic sense of trust in other human 
beings (Cherlin, 2002). Later, they provide the guidance, support and discipline children need in order to become competent members of their society.

Parenthood is important in the overall development and preparedness of children's later academic, social and career lives. In many comparably industrialized countries, the family has undergone a series of profound changes during the past 30 years that have diversified its form and as a result adolescents' daily experience (Steinberg, 2002). These series of changes have also been experienced in the Kenyan family. The family structure has evolved due to industrialization, education, poverty and widespread dual parental employment. These society wide changes exert many influences on parenthood, on interactions between parents and children and consequently on children and their development (Kendall, 2007). There are basically two main types of parenthood. These are dual and single parenthoods. Dual parenthood is where a man and a wife live together as husband and wife and take care of their children. Single parenthood is where one of the parents raises the children alone. The other parent is absent either due to divorce, death, choice or even due to teenage pregnancy. The single parent family is headed either by a father or a mother. Increased rates of divorce, childbearing outside marriage and maternal employment as well as a changing international economy and accelerating geographical mobility all have dramatically altered the world in which children and adolescents grow up. The divorce rate, the proportion of single parent families and the rate of maternal employment have been high (Chakravarty, 2007). Questions abound whether these changes have weakened the family's influence over young people or, have harmed them. Some of the problems encountered by the young have been attributed to these changes in the family. The dual and the single parent families are also found in the Kenyan society as found out in a study carried out in 1995 by Family support institute in conjunction with UNICEF (Family Support Institute as cited in Kimani, 2006).

Parents play a critical role in their children's cognitive and emotional development. They also provide the nurturance and discipline, promote language development and act as teachers and are responsible for monitoring and managing the care the child receives from other adults (Fomby \& Cherlin, 2007).Though many factors influence development of children, parenthood is the final common pathway to childhood oversight and care giving, development and stature, adjustment and success (Henslin, 2006).

\subsection{Dual Parenthood}

Children should have both a father and mother in the home (Oslon \& Defrain, 2002). When the actual situation falls short of the ideal, the quality of family life may be affected. Most infants in dual-parent homes form secure attachments to their fathers during the later half of the first year particularly if the father has a positive attitude about parenting, is extraverted and agreeable, spends a lot of time with them and is a sensitive caregiver (Henslin, 2006). Research conducted in Australia, Israel, India, Italy, Japan and the U.S.A. reveals that mothers and fathers in all these societies tend to play somewhat different roles in a baby's life (Oslon \& Defrain 2000). In Kenya, two parent families constituted $45 \%$ of the families as found out in a study carried out in 13 districts in 1995( Family support Institute as cited in Kimani, 2006)

Two parent families are advantageous over single parent families in that biological fathers make distinctive, irreplaceable contributions to their child's welfare as fathers offer a strong male role model to sons (Giddens, 2005). They also play the role of disciplinarian for trouble-prone children. Fathers provide their daughters with a male perspective on heterosexual relationships and also through their unique play styles. Where fathers are more generative, the children have greater educational and occupational success (Henslin, 2002). Studies suggest that fathers' involvement with daughters may be more consequential when they are adolescents than when they are younger. As for boys, father's involvement may be more consequential when they are pre-adolescents than when they are older since this is the time when they must separate from their mothers and identify as male (Cherlin, 2002).

According to O'Donnell (2002), the dual parent family offers the following advantages to the children:

i. Increased educational opportunities

ii. The children are more easily cared for emotionally and financially by both parents.

Children from families with two biological parents are more likely to be well adjusted than are children from other family configurations (Rice, 1990). Dual parents tend to be more involved with their children for example taking them to cultural and recreational activities, doing things with them at home and talking with them about their problems than are parents in single parent families (Oslon \&Defrain, 2000). Functions of a family may differ from society to society. However, a primary function of the family is to provide for the children's daily requirements (Lamana, 1988). Parents are expected to care for their children and be responsible for their moral and intellectual development (Hagee, 2006). The family is primarily responsible for children's socialization. The family acts to provide emotional security by countering family members' feelings of isolation and giving them a sense of belonging (Oslon \&Defrain, 2000). 


\subsection{Single Parenthood}

In the modern Kenya, there is a generation, both male and female that wants children, peace and happiness without the loss of personal freedom, incessant supremacy, financial freedom, the petty squabbles and emotional upheavals that have become synonymous with the institution of marriage (Malanda, 2009). Life in a singleparent family can be extremely stressful in both economical and emotional terms (Schaefer, 2006). Single parent families face many of the same challenges that other families face, yet they must also cope with additional unique challenges. Single parents tend to feel overloaded with too much responsibility and too much to do (Howse, 1998). The difficulties of providing single handed for their own and their children's physical, social and emotional needs often result in role overload and fatigue. The impact on children growing up in single parent families is debatable. However, children raised up in single parent families will differ from those brought up in two parenting families (Giddens, 2005). The difference will be due to inadequate parental attention and lack of social ties. Separation or divorce weakens the connection between child and the absent parent In comparison to the two-parent family, the single parent family however offers the child especially the older child an opportunity for real responsibility (Lamana, 1988). Single parents may discuss a wider range of matters with their children. The presence of only one parent is sometimes a handicap, even after lower income is taken into account. One danger of single-parent family is the loss of the parent-child relationship and the development of a buddy-buddy friendship between mother and child. In such families, the child is usually considered to be more mature than he is (Howse, 1988). The parent relies on the child for emotional support, help in decision making, freely expressing personal difficulties such as bitterness towards the ex-spouse and frustrations with the numerous burdens and social isolation (Kendall, 2002). By abducting their roles, the parents force the child to acquire the role of peer and partner left vacant. The parent may be gratifying her or his needs but the child is thrust into a level of development for which he or she is not prepared for and the emotional needs of the child are neglected (Cherlin, 2002). At its extreme, the parent-child relationship can become inverted where a reversal of roles occurs in which the child takes care of the parent.

Father -headed single parent homes are more common than they used to be. Father-headed families account for about $17 \%$ of all single-parent families in the U.S.A. (Eggebeen \& Litcher, 1991). Despite statistics being scanty in Kenya, father-headed single parent families are not a new phenomenon. Some men are choosing to have children, live with them and bring them up without the presence of the mother. This is a current emerging trend among some men who feel that they want to have the joys of having children without necessarily being married (Malanda, 2009). The strengths of single-fatherhood include the fact that they are able to watch their children grow and they enjoy the love between them and their children. Single-fathers however go through financial constraints. They are also likely to have less practice than mothers in juggling parental and professional roles and they worry that they do not spend enough time with their children (Insel \&Roth, 2002). Single fathers like single mothers find that one of their greatest challenges is balancing the demands of work and parenthood (Zanden, 2003). Most single fathers are concerned about not spending enough time with their children. Single fathers undergo considerable intrapersonal stress as they take on the responsibility of raising their children (Rice, 1990). The single fathers are often forced to change their circle of friends and to rebuild their social life. They are also faced with the dilemma of finding adequate child care services.

Single fathers are under additional intrapersonal pressure to prove their competency as parents. Part of their stress arises because they are often forced to change their circle of friends and to rebuild their social life (Rice, 1990). Findings reveal that the earlier a boy is separated from his father and the longer the separation is, the more affected the boy will be in his early years. Fathers have an effect on daughters as they play a significant role in encouraging their daughter's feminine development. The father's acceptance and reinforcement of his daughter's femininity greatly facilitates the development of her self-concept (Henslin, 2006). Interaction with a competent father also provides the girl with basic experiences that help in her relationships with other males. Girls who have positive relationships with their fathers are more likely to be able to obtain satisfaction in the later heterosexual relationships (Zanden, 2003).

A single parent family may also be headed by the mother. In most instances, when youngsters live with only one of their natural parents, it is nearly always their mother (Steinberg, 2002). This is because mothers spend far more time with children, do most of the care-taking and if the family breaks up are far more likely to raise the children as single parents (Chakravarty, 2007). Mothers with child custody experience many stresses. They are more likely to experience poverty than male-headed families due to limited finances (Lauer \& Lauer, 2002). In recent years, the rate of poverty among families headed by a female with no husband present has been more than twice that of the general population as about half of all the millions of children living in poverty are in female-headed families (Steinberg, 2002). 54\% of children living in female- headed homes live in poverty compared to $10 \%$ of those in two-parent homes (Eggebeen \&Lichter, 1991). Loneliness is common for most single mothers. Children in mother only families however may also show more adolescent deviance, higher susceptibility to peer pressure and increased substance abuse (Rice, 1990). Children who grow apart from their 
biological fathers score lower on standardized tests, report poorer grades and view themselves as having less academic potential than children who grow up with both biological parents (Amato, 2005). These effects are similar for boys and girls children who grow apart from their biological fathers. They also experience a higher prevalence of behavioural and psychological problems such as shyness and aggression than other children (Santrock, 2005).

\section{OBJECTIVE OF THE STUDY}

To establish the difference in academic performance of students from dual and single parenthoods in public day secondary schools in Nakuru Municipality.

\section{RESEARCH QUESTION}

What is the difference in academic performance of students from dual and single parenthoods in public day secondary schools in Nakuru Municipality?

\section{METHODOLOGY}

This study adopted cross-sectional survey design. The target population comprised of form 3 students, both boys and girls in the public day secondary schools in Nakuru Municipality. The study used a sample size of 5 schools of the population of public day secondary schools. The 5 schools were sampled randomly. Students' sample size was 145 . Out of the 145 students, 78 students came from dual parent families, 39 boys and 39 girls. Sixty seven students hailed from single parent families, 37 boys and 30 girls. Stratified Random sampling was employed to sample students from dual parenthood type. Purposive sampling was employed to sample students from single parenthoods. Two sets of questionnaires were used to collect data. Data was analyzed using Statistical Package for Social Sciences for Windows.

\section{FINDINGS AND DISCUSSIONS}

Students' Academic Performance

The objective of this study aimed at establishing if there were any significant differences in academic performance of students by their parenthood types in public day secondary schools in Nakuru municipality. To address this objective, the students were required rate themselves academically and also indicate their individual mean grades for the previous four terms.

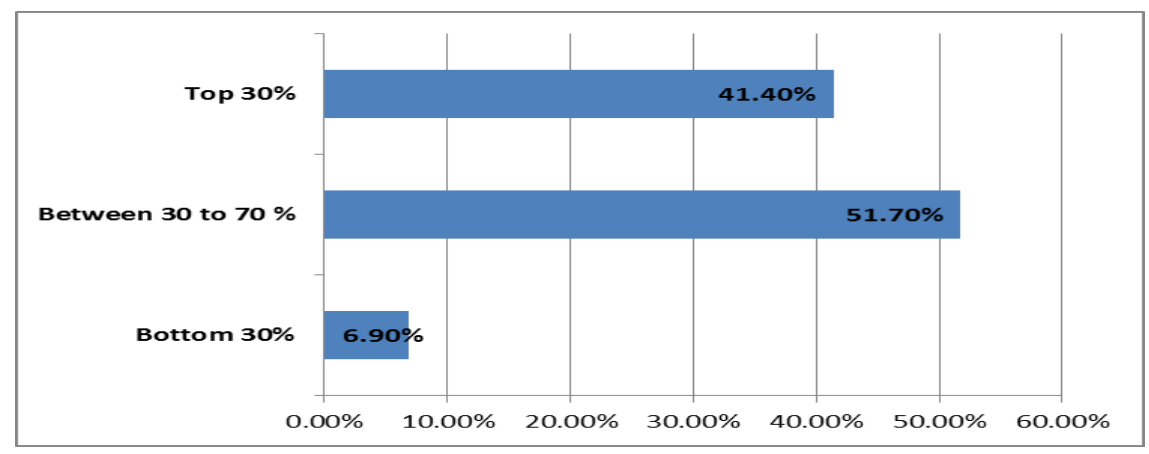

Figure 1: Students' Percentile Group ratings in Previous Terms' Performance in Exams

As shown in figure 1, 6.9\% of the students rated themselves as being in the bottom $30 \%$ in performance in exams, $51.7 \%$ of the students rated themselves as being between $30 \%$ and $70 \%$ in their performance in exams, and $41.4 \%$ of the students rated themselves as being in the top $30 \%$ in performance in exams. This is in relation to how they had performed in their previous term's exams. Majority of the students rated themselves as being average. This was also reflected in the mean grades the students had scored in the previous four terms. This then means that the students did understand what was expected of them from the questionnaire items. It is also an implication that that they were honest in filling in the research items.

The teacher counsellors also responded to the item on which students performed better academically. Seventy percent of teacher counsellors agreed that students from two parent families performed better academically than students from dual parent families. Ten percent of the teacher counsellors were undecided on which students performed better with $20 \%$ of them indicating that student from single parent families performed better academically than those from dual parent families

Table 1 Summary of Students' Family Type and their Average Mean Scores for the Previous Four Terms 


\begin{tabular}{|c|c|c|c|c|c|}
\hline \multicolumn{4}{|c|}{$\begin{array}{l}\text { Average Mean Scores for the Previous } \\
\text { Four Terms }\end{array}$} & \multirow[t]{2}{*}{$\begin{array}{r}\text { Total } \\
\text { Students } \\
\end{array}$} & \multirow[t]{3}{*}{$\begin{array}{l}\text { Avera } \\
\text { Scores } \\
\end{array}$} \\
\hline Category & High & Average & Low & & \\
\hline Mean grade & $\mathrm{A}-\mathrm{B}+\mathrm{B}$ & B- C + C. C- & $D+$ to- $E$ & & \\
\hline $\begin{array}{l}\text { Students' Frequencie } \\
\text { from dual parents }\end{array}$ & 5 & 66 & 7 & 78 & 6.70 \\
\hline $\begin{array}{l}\text { Students' Frequencies } \\
\text { From single parents }\end{array}$ & 1 & 47 & 19 & 67 & 5.79 \\
\hline Total & 6 & 113 & 26 & 145 & 6.25 \\
\hline
\end{tabular}

The students filled in the mean grades they had scored for the previous four terms. This was in consultation and with assistance from the class teachers of the concerned classes to ensure that the correct mean grades were recorded. The average mean grade from the four previous mean grades indicated by each student was first calculated. The average mean grade of students from dual parenthood was then calculated and compared with the average mean grade of students from single parenthood families. Students were put into two categories. These were those from single parent families and those from dual parent families.

The mean grades got from the students were ranked into three categories. These were low, average and high in relation to the mean grades attained and their frequencies as summarised in table 1 . The high category ranged from grades A to B, average from grades B- to C- and low from grades D+ to E. The students were put into two categories with regard to their parenthood type that is dual and single parenthood. Five students from dual parenthood and one student from single parenthood were ranked in the high category giving a total of 6 students. No student scored a mean of A from both parenthood types. This could be because the students in day schools are admitted to form one with lower K.C.P.E. marks. It may also be due to the fact that much revision time is wasted as students commute to and from home to school daily.

In the average category, 60 students from dual parents and 47 students from single parents were ranked. Students from dual parents were more in the higher ranked categories. Seven students from dual parents were ranked in the low category compared to 19 students from single parenthoods. In overall rankings, more students from dual parent family were ranked in the high and average categories than the students from single parent families. There were more students in the low category from single parents. The mean score for the students from dual parents was 6.70. The mean score of students from single parents was 5.79. Students from dual parents scored a higher mean grade than students from single parent families. The average mean score for the 145 sampled students was 6.25 points. This is a better performance compared to what the mean score for the municipality in the 2008 K.C.S.E results were. This could be because the students are yet to cover the form four syllabus which could result in a lowered final grade due to more workload in the final year.

T-test was computed using the students' average mean grades to determine if there was any statistically significant difference in academic performance between students from single and dual parenthoods.

Table 2Achievement Differences in Academic Performance between Students from Dual and Single Parents.

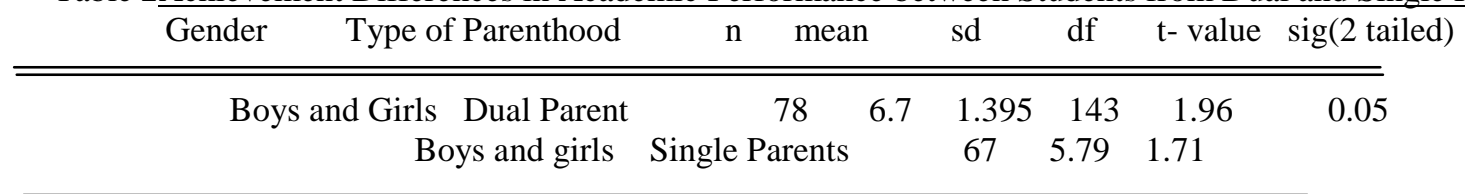

The results indicated that $\mathrm{t}=1.96, \mathrm{P}<0.05$. This implies that there is a statistically significant difference in academic performance of students from dual and single parenthoods in public day secondary schools in Nakuru municipality. Students from dual parenthoods performed better academically than those from single parenthoods as found out in public day secondary schools in Nakuru Municipality. According to O'Donnell (2002), the dual -parent family offers increased educational opportunities to the students. Lauer \&Lauer (2002) stipulates that students in single parent families tend to have lower academic achievements compared to those in two parent families. This could be attributed to the fact that those from two parent families are sent home less often due to school fees problems compared to those from single parent families in Nakuru Municipality. Students from single- parent families are more likely to have poor academic achievement and higher school absentee than 
students from two -parent families (Kendall, 2007). Students from single parent families also may be affected negatively in their academic performance due to the absence a role model and the father as a disciplinarian

\section{CONCLUSION}

The study concluded that type of parenthood did have an influence on students' academic performance in public day secondary schools in Nakuru Municipality. Students from dual parenthoods performed better academically than those from single parenthoods.

\section{RECOMMENDATIONS}

Based on the findings of the study, it was recommended that the Ministry of Education should intervene for the students from single parent families through development of appropriate counselling materials. The students need to be counselled on how to cope with the challenges they encounter as a result of growing up in a single parent family. The Ministry of Education should also organise workshops to train the counselling teachers so that they are well equipped and prepared to handle the various challenges they may encounter in the process of counselling the students.

\section{REFERENCES}

1. Oslon, D.H., Defrain, J. (2000).Marriage And The Family. Diversity And Strengths. Toronto: Mayfield Publishing Company.

2. Henslin, M.J., (2006). Sociology: A Down To Earth Approach. 6th Edition. New York.

3. Kimani, J.M., (2006). Influence Of Parent Marital Status On Self-Esteem, Discipline And Interpersonal Relationships Among Secondary School Students Within Nakuru Municipality, Kenya: Egerton University (Unpublished Thesis).

4. Lauer, H.R., Lauer, C.J., (2002). Social Problems And The Quality Of Life. 8th Edition. New York: Mcgraw Hills.

5. Cherlin, A.J., (2002). Public \& Private Families. An Introduction, 3rd Edition. New York: Mcgraw Hills.

6. Steinberg, I., (2002). Adolescence 6th Edition. New York: Mcgraw Hill Higher Education

7. Kendall, D., (2007). Sociology In Our Times. The Essentials. Canada: Thomson Wadsworth.

8. Chakravarty, M., (2007). Child Psychology. New Delhi: Ajay Verma.

9. Eggebeen, D.J., Lichter, D.T., (1991). Race Family Structure And Changing Poverty Among American Children .American Sociological Review 56, 801-817

10. Fomby, P., Cherlin, A.J., (2007). Family Instability And Child Well-Being, Am Social Rev.72:181-204

11. Henslin, M.J., (2006). Sociology: A Down To Earth Approach. 6th Edition. New York.

12. Giddens. A., (2005). Introduction To Sociology, 5th Edition. U.S.A.: W.W. Norton And Company.

13. O'Donnell, G., (2002). Mastering Sociology. 4th Edition. Great Britain : Pal Grave Publisher

14. Rice, K., Mulkeen, P., (1995). Relationships With Parents And Peers. A Longitudinal Study OfAdolescents' Intimacy .Journal Of Adolescent Research 10, 338-357

15. Hagee, J., (2006). What Every Man Want In A Woman: What Every Woman Want In A Man. U.S.A.: Charisma House

16. Malanda,T.,(12th Oct 2009).No Husbands, Just Pass Me A Sperm. The Standard Newspaper, Crazy Monday,Pp8

17. Howse . K., (1988). Family Matters: A Guide To Family Life. England: Stan Borough Press Ltd

18. Eggebeen, D.J., Lichter, D.T., (1991). Race Family Structure And Changing Poverty Among American Children .American Sociological Review 56, 801-817

19. Zanden, J.W.V., (2003).Human Development. New York: Mcgraw Hills.

20. Amato, P.,(2005). The Impact Of Family Formation, Change On The Cognitive, Social And Emotional Child. 15 (2): 75-96.

21. Santrock, W.J., (2005). A Topical Approach To Life-Span Development 2nd Edition. New York: Mcgraw Hills. 